\title{
Health and Health Related Quality of Life of Children Living with HIV Infected Parents
}

\author{
Priyanka Chauhan', Sunit Pathak ${ }^{2 *}$ and N C Prajapati ${ }^{3}$ \\ ${ }^{1}$ Dept of Pediatrics, KGMU, Lucknow, India \\ ${ }^{2} \mathrm{FH}$ Medical College, Tundla, Firozabad, India \\ ${ }^{3} \mathrm{GMC}$, Badaun, UP, India
}

\begin{abstract}
Objective: To study the health and health related quality of life of children living with HIV infected parents using Pediatric Quality of Life Inventory (PedsQL) TM 4.0 Generic Core Scales.

Methods: The study was conducted from January 2013 to October 2014 at S. N. Medical College, Agra, ART centre and pediatrics OPD. The Pedsql generic core version 4.0 was administered to 300 children in the age group of 8-18 years living with HIV infected parents and 300 controls who visited the pediatric OPD for minor ailments.

Results: In this study it was found that children living with HIV infected parents had lower mean weight(26.89 vs $30.76 \mathrm{~kg})$, height(1.09 vs 1.35 metres) and body mass index (15.73 vs 17.16$)$ compared with controls. The percentage of children not attending the school for more than six months was also significantly higher in the study group ( $32 \%$ vs $15 \%$ in controls. Their Pedsql scores were lower in emotional, social and school domains as compared with the controls.

Conclusion: These findings are along expected lines, it is vital to establish a baseline of socioeconomic and physical parameters of such children in Indian context. This knowledge is vital to plan a meaningful policy intervention and to measure its efficacy. These findings can guide in the development of future interventions that promote care and support of children living in HIV/AIDS affected families. we feel more such studies are required in future to realise the big picture.
\end{abstract}

Keywords: HIV, Peds QL,HRQOL, Social and School Domain

\section{Introduction}

HIV in children is a major health problem which is increasingly becoming prominent cause of childhood morbidity and mortality in India. The total number of people living with HIV in India is estimated at 2.4 million in 2009 with $4.4 \%$ children less than 15 years of age (NACO) (1).

A search of the literature has shown that there has been very limited research on the HRQOL of children living with HIV infected parents in India. The information gathered on children living with HIV infected parents, including children orphaned by AIDS, would be of benefit to all the health team members, and family members involved in taking care of these young children and would assist in determining the resource allocation that is necessary in terms of social, emotional and school support that would optimise the quality of life of these children. In addition, the specific domains assessed using the modified version of PedsQL 4.0 Generic Core Scales may highlight specific aspects of quality of life in children. The aim of this study was to study the health and health related quality of life of children living with HIV positive parents through Pedsql 4.0.

\section{Material \& Methods}

The present cross-sectional study was conducted in Department of Paediatrics and ART Centre, SN Medical College, Agra (U.P) from January 2013 to October 2014.

Children of age 8 to 18 years of HIV infected parents, attending OPD of ART Centre at SN Medical College Agra during the study period were enrolled in the study group. Child suffering with HIV infection, children suffering with cognitive or communicative disabilities or psychotic disorders and children of parents diagnosed for HIV infection of less than 6months duration at the time of enrolment and children with no parent alive were excluded from the study.

Age and sex matched children in the age group of 8-18 yrs of HIV/AIDS negative/not tested parent/s, attending Pediatrics OPD for minor illnesses were included in the control group.

Guardian/parents of the child in presence of the child were briefed about the objectives of the study and written consent was obtained. At the time of enrolment in the study a detailed profile of the child was recorded 
on a predesigned, pretested semi structured performa (enclosure). A complete physical examination of each child was done and parameters recorded. Ethical clearance was taken from institutional review board.

Paediatric Quality Of Life Generic Core Scale Version 4.0(PedsQL 4.0) (2) in Hindi language was used in all children of the study group for which permission was sought from Dr James W.Varni, who owns the copyrights of PedsQL. PedsQL 4.0 measures the health dimensions (called domains) of physical, emotional, social and school functioning of the child through various questions (called items). It has 8 items for physical functioning domain and 5 items each for emotional, social and school functioning domains (total 23 items). Two methods for administration of the instrument were self-administration and proxy administration. Children $\leq 12$ years opted for proxy method and children $>12$ years, for self administration method.

Each item in different domain was assessed and scored by two methods Likert scoring and Reverse scoring. Likert score ranges from $0-4$ ( 0 is never, 1 is almost never, 2 is sometimes, 3 is frequently and 4 is almost always).

In reverse scoring the Likert score of each item in the domain was transformed on a scale of $0-100$ in a reverse manner where 0 is 100,1 is 75,2 is 50,3 is 25 and 4 is 0 . By reverse scoring the HRQOL was plotted on a score of 0-100 where reverse score ' 0 'means severely affected and ' 100 ' means near normal. The total score in each domain was calculated separately and it denotes the QOL related to that domain ie Physical, Social, Emotional and School. HRQOL for psychosocial functioning was obtained by combining the scores of social, emotional and school functioning domains. A total score for all the domains was calculated by summing up the scores of all the domains and it denotes overall HRQOL.

\section{Result}

Fom January 2013 to October 2014, 556 HIV infected parents with at least one child rin the age group of 8-18 years and fulfilling the inclusion criteria visited the ART centre for consultation. 513 such parents were contacted and were pursued to take part in the study and bring their children on the next visit. Only 300 parents and their eligible children turned up during the study period and were enrolled in the study.

Table-1 shows the demographic profile of children and caregivers in the study and the control group.

In the present study it was observed that reverse scores ranged from 0-100 and the mean total reverse score was 77.16. Among individual domains children scored best in their physical scores (87.07) but were less in emotional domain (72.53), social domain (79.65) and school domain (69.40). The psychosocial score by reverse scoring was 73.86. (Table-2)

The association of Pedsql scores with multiple independent variables was performed. Lower pedsql scores were recorded in older age group, children not attending school, living in nuclear families, with single parent alive, and lower socioeconomic status. (Table-3)

For the categorical variables (gender, hiv status etc.) the data was analysed as frequency and percentage and chisquare test was applied for comparisons. For continuous variables (weight, height, reverse scores) mean and standard deviations were calculated and comparison was done using unpaired student-t-test. Spss20 was used to calculate the results. P-values less than 0.05 were considered significant.

Table-1: Demographic profile of children and caregivers in study and control group:

\begin{tabular}{|c|c|c|c|}
\hline \multicolumn{2}{|c|}{$\begin{array}{l}\text { Profile } \\
\text { Children }\end{array}$} & \multirow{2}{*}{$\begin{array}{c}\text { Control group }(\mathrm{n}=\mathbf{3 0 0}) \\
171(57 \%)\end{array}$} & \multirow{2}{*}{$\begin{array}{l}\text { Study group }(n=300) \\
\qquad 162(54 \%)\end{array}$} \\
\hline & $\leq 12$ years & & \\
\hline Rye givup & $>12$ years & $129(43 \%)$ & $138(46 \%)$ \\
\hline \multirow{2}{*}{ Gender $^{+}$} & Male & $181(60 \%)$ & $165(55 \%)$ \\
\hline & Female & $119(40 \%)$ & $135(45 \%)$ \\
\hline \multirow{2}{*}{ Schooling $^{+}$status } & Attending school & $256(85 \%)$ & $204(68 \%)$ \\
\hline & Not attending school & $44(15 \%)$ & $96(32 \%)$ \\
\hline Weight (kilogram)* & & $30.76 \pm 8.593$ & $26.89 \pm 7.009$ \\
\hline Height (metres) ${ }^{*}$ & & $1.35 \pm 0.480$ & $1.09 \pm 0.288$ \\
\hline $\mathrm{BMI}^{*}$ & & $17.16 \pm 3.357$ & $15.73 \pm 2.320$ \\
\hline $\begin{array}{l}\text { Relationship with caregiver }{ }^{+} \\
\text {Parents } \\
\text { Grandparents } \\
\text { Other relatives }\end{array}$ & & $\begin{array}{c}290(96.7 \%) \\
7(2.3 \%) \\
3(1 \%) \\
\end{array}$ & $\begin{array}{c}249(83 \%) \\
34(11.3 \%) \\
17(5.7 \%) \\
\end{array}$ \\
\hline
\end{tabular}




\begin{tabular}{|c|c|c|}
\hline $\begin{array}{c}\text { Profile } \\
\text { Children }\end{array}$ & Control group $(n=300)$ & Study group $(n=300)$ \\
\hline $\begin{array}{l}\text { HIV status of Father } \\
\text { Positive } \\
\text { Negative } \\
\text { Unknown }\end{array}$ & 300 & $\begin{array}{c}214 \\
38 \\
48\end{array}$ \\
\hline $\begin{array}{l}\text { HIV status of } \text { Mother }^{+} \\
\text {Positive } \\
\text { Negative } \\
\text { Unknown }\end{array}$ & 300 & $\begin{array}{l}171 \\
93 \\
36\end{array}$ \\
\hline $\begin{array}{l}\text { Lively status of parents } \\
\text { Both alive } \\
\text { Only Mother alive } \\
\text { Only Father alive }\end{array}$ & $\begin{array}{c}290 \\
7 \\
3\end{array}$ & $\begin{array}{c}218 \\
48 \\
36\end{array}$ \\
\hline Variables in the Study group & & \\
\hline $\begin{array}{l}\text { Parents' HIV status }{ }^{+} \\
\text {Disclosed to child } \\
\text { Not disclosed }\end{array}$ & \multicolumn{2}{|c|}{$\begin{array}{l}114 \\
186\end{array}$} \\
\hline $\begin{array}{l}\text { Disclosed to relatives } \\
\text { Not disclosed to relatives }\end{array}$ & \multicolumn{2}{|c|}{$\begin{array}{l}177 \\
123 \\
\end{array}$} \\
\hline $\begin{array}{l}\text { Mode of administration of } \mathrm{HRQOL}^{+} \\
\text {Self-administered } \\
\text { Proxy administered }\end{array}$ & \multicolumn{2}{|c|}{$\begin{array}{l}120 \\
180 \\
\end{array}$} \\
\hline
\end{tabular}

+ values are given as frequency and (percentage)

* values are given as mean \pm standard deviation

Table 2: Likert Scores and Reverse scores of the Pedsql Generic core scale version 4.0 in the study group.

\begin{tabular}{|c|c|c|}
\hline Domain & Likert score & Reverse score \\
\hline Physical(n=300) & 2.073 & 87.07 \\
\hline Emotional(n=300) & 2.731 & 72.53 \\
\hline Social $(n=300)$ & 2.534 & 79.65 \\
\hline School(n=204) & 2.833 & 69.40 \\
\hline Psychosocial(n=204) & 2.699 & 73.86 \\
\hline Total $(n=204)$ & 2.543 & 77.16 \\
\hline
\end{tabular}

Table 3: Variables affecting Pedsql scores in the Study group:

\begin{tabular}{|c|c|c|c|c|c|c|}
\hline \multicolumn{2}{|l|}{ Variable } & Physical score & Emotional score & Social score & School score & Total score \\
\hline \multirow{2}{*}{ Age } & $\leq 12$ years & \multirow{2}{*}{$\begin{array}{l}86.37( \pm 14.18) \\
87.41( \pm 11.48) \\
P \text { value } 0.550\end{array}$} & \multirow{2}{*}{$\begin{array}{c}78.43( \pm 17.69) \\
65.44(17.86) \\
\text { Pvalue }<0.001\end{array}$} & \multirow{2}{*}{$\begin{array}{l}80.01( \pm 14.44) \\
79.22( \pm 13.86) \\
P \text { value } 0.780\end{array}$} & \multirow{2}{*}{$\begin{array}{l}73.13( \pm 21.89) \\
79.48( \pm 17.34) \\
P \text { value } 0.071\end{array}$} & \multirow{2}{*}{$\begin{array}{l}63.89( \pm 17.05) \\
74.13( \pm 15.13) \\
P \text { value } 0.203\end{array}$} \\
\hline & $>12$ years & & & & & \\
\hline \multirow{2}{*}{ Gender } & Male & \multirow{2}{*}{$\begin{array}{l}89.64( \pm 12.16) \\
83.86( \pm 13.41) \\
P \text { value } 0.027\end{array}$} & \multirow{2}{*}{$\begin{array}{l}74.36( \pm 17.32) \\
70.23( \pm 20.54) \\
P \text { value } 0.280\end{array}$} & \multirow{2}{*}{$\begin{array}{l}81.00( \pm 14.16) \\
77.95( \pm 14.03) \\
P \text { value } 0.288\end{array}$} & \multirow{2}{*}{$\begin{array}{l}70.66( \pm 20.41) \\
67.76( \pm 20.98) \\
P \text { value } 0.570\end{array}$} & \multirow{2}{*}{$\begin{array}{l}78.91( \pm 16.01) \\
74.95( \pm 17.24) \\
P \text { value } 0.310\end{array}$} \\
\hline & Female & & & & & \\
\hline \multirow{3}{*}{ Type of family } & Nuclear & \multirow{3}{*}{$\begin{array}{l}85.59( \pm 14.06) \\
88.03( \pm 11.47) \\
P \text { value } 0.380\end{array}$} & \multirow{3}{*}{$\begin{array}{l}69.23( \pm 20.02) \\
74.67( \pm 17.87) \\
P \text { value } 0.130\end{array}$} & \multirow{3}{*}{$\begin{array}{l}74.23( \pm 14.58) \\
83.17( \pm 12.72) \\
P \text { value } 0.003\end{array}$} & \multirow{3}{*}{$\begin{array}{l}65.19( \pm 20.31) \\
72.25( \pm 20.47) \\
P \text { value } 0.250\end{array}$} & \multirow{3}{*}{$\begin{array}{l}73.56( \pm 15.01) \\
79.53( \pm 13.45) \\
P \text { value } 0.273\end{array}$} \\
\hline & & & & & & \\
\hline & Joint & & & & & \\
\hline \multirow{3}{*}{$\begin{array}{l}\text { Lively status of } \\
\text { parents }\end{array}$} & Both alive & \multirow{3}{*}{$\begin{array}{l}88.52( \pm 11.22) \\
87.64( \pm 6.499) \\
P \text { value } 0.740\end{array}$} & \multirow{3}{*}{$\begin{array}{l}77.73( \pm 16.76) \\
66.36( \pm 20.01) \\
P \text { value } 0.010\end{array}$} & \multirow{3}{*}{$\begin{array}{l}84.92( \pm 11.98) \\
70.45( \pm 10.22) \\
\text { Pvalue }<0.001\end{array}$} & $72.76( \pm 20.03)$ & \multirow{3}{*}{$\begin{array}{l}80.98( \pm 15.24) \\
72.50( \pm 13.80) \\
P \text { value } 0.301\end{array}$} \\
\hline & sotn alive & & & & $65.56( \pm 18.45)$ & \\
\hline & Single alive & & & & $P$ value 0.340 & \\
\hline
\end{tabular}




\begin{tabular}{|c|c|c|c|c|c|c|}
\hline \multicolumn{2}{|l|}{ Variable } & Physical score & Emotional score & Social score & School score & Total score \\
\hline \multirow{3}{*}{$\begin{array}{l}\text { Disclosure of } \\
\text { parents' HIV } \\
\text { status }\end{array}$} & Not Disclosed & \multirow{3}{*}{$\begin{array}{c}86.05( \pm 11.79) \\
87.79( \pm 13.82) \\
P \text { value } 0.51\end{array}$} & \multirow{3}{*}{$\begin{array}{l}85.49( \pm 12.03) \\
63.36( \pm 17.38) \\
\text { Pvalue }<0.001\end{array}$} & \multirow{3}{*}{$\begin{array}{l}83.05( \pm 14.40) \\
77.24( \pm 13.51) \\
P \text { value } 0.043\end{array}$} & \multirow{3}{*}{$\begin{array}{l}77.14( \pm 19.22) \\
63.85( \pm 19.88) \\
P \text { value } 0.008\end{array}$} & \multirow{3}{*}{$\begin{array}{l}82.93( \pm 14.36 \\
73.06( \pm 16.14 \\
P \text { value } 0.062\end{array}$} \\
\hline & & & & & & \\
\hline & Disclosed & & & & & \\
\hline \multirow{3}{*}{$\begin{array}{l}\text { Socioeconomic } \\
\text { status }\end{array}$} & Lower & \multirow{3}{*}{$\begin{array}{c}85.58( \pm 13.84) \\
91.04( \pm 9.48) \\
P \text { value } 0.060\end{array}$} & \multirow{3}{*}{$\begin{array}{l}71.39( \pm 18.90) \\
75.56( \pm 18.67) \\
P \text { value } 0.320\end{array}$} & \multirow{3}{*}{$\begin{array}{l}77.29( \pm 14.38) \\
85.93( \pm 11.35) \\
P \text { value } 0.006\end{array}$} & \multirow{3}{*}{$\begin{array}{l}65.78( \pm 21.55) \\
76.82( \pm 16.37) \\
P \text { value } 0.038\end{array}$} & \multirow{3}{*}{$\begin{array}{l}75.01( \pm 17.17) \\
82.34( \pm 13.97) \\
P \text { value } 0.020\end{array}$} \\
\hline & & & & & & \\
\hline & Middle & & & & & \\
\hline \multirow[b]{2}{*}{ Schooling* status } & $\begin{array}{l}\text { Not Attending } \\
\text { school }\end{array}$ & \multirow{2}{*}{$\begin{array}{c}84.58( \pm 13.14) \\
89.46( \pm 8.40) \\
P \text { value } 0.070\end{array}$} & \multirow{2}{*}{$\begin{array}{l}62.34( \pm 20.90) \\
73.65( \pm 15.67) \\
P \text { value } 0.032\end{array}$} & \multirow{2}{*}{$\begin{array}{l}74.30( \pm 15.28) \\
82.83( \pm 12.33) \\
P \text { value } 0.005\end{array}$} & \multirow[b]{2}{*}{ Not calculated } & \multirow[b]{2}{*}{ not calculated } \\
\hline & $\begin{array}{l}\text { Attending } \\
\text { school }\end{array}$ & & & & & \\
\hline \multirow{2}{*}{ BMI of child } & $\geq-2 S D$ & \multirow{2}{*}{$\begin{array}{l}87.64( \pm 12.15) \\
85.86( \pm 13.40) \\
P \text { value } 0.132\end{array}$} & \multirow{2}{*}{$\begin{array}{l}73.34( \pm 18.32) \\
69.22( \pm 22.54) \\
P \text { value } 0.280\end{array}$} & \multirow{2}{*}{$\begin{array}{l}81.00( \pm 14.15) \\
77.95( \pm 14.03) \\
P \text { value } 0.288\end{array}$} & \multirow{2}{*}{$\begin{array}{l}71.65( \pm 19.40) \\
68.71( \pm 19.90) \\
P \text { value } 0.570\end{array}$} & \multirow{2}{*}{$\begin{array}{l}78.40( \pm 16.01) \\
75.43( \pm 17.24) \\
P \text { value } 0.243\end{array}$} \\
\hline & $<-2 S D$ & & & & & \\
\hline
\end{tabular}

* As 96/300 children were not attending school, the school score and total score could not be calculated

\section{Discussion}

In our study we found that children living with HIV infected parents had lower mean weight, height and body mass index compared with controls. The percentage of children not attending the school for more than six months was also significantly higher in the study group. Their Pedsql scores were lower in emotional, social and school domains. School score was the most affected domain followed by emotional domain. The physical domain was the least affected. The HRQOL was significantly affected by age of child, survival status of parents, type of family the child lives in, socioeconomic status of family, schooling, disclosure of parents' HIV status.

$32 \%$ children in the study group were not attending the school, for duration of more than 6 months, at the time of study. Regarding reasons for dropouts, poor economic condition and social stigmas associated with their parents HIV status were the major issues. In the studies by Tao Xu et al (3) and Sengendo and Nambi et al (4) in Uganda, the percentage of dropouts from school was $18 \%$ and $45 \%$ respectively

In our study $19 \%$ of children had their BMI below 2 Standard deviation (Underweight) (Table 1). It is slightly more than reported by Chinqing Lin et al (5).

On comparing the HRQOL scores with respect to age the scores were significantly lower in the emotional domain in children greater than 12 years (Table-3). It could be due to children of the older age being able to understand the disease and social stigmas associated with HIV from which their parents were suffering. Other reason could be that children in the older age group had opted for self administration method for response and are their best judges regarding their emotions. The HRQOL scores were better in all domains in children whose both parents are alive. This difference is statistically significant in the emotional and social domains only. Our findings showed that disclosure of parental HIV/AIDS status to the child affected the HRQOL of their children in the emotional, social and school domains (table 3 ) similar to that reported by Tao Xu et al (3) and Rotheram-Borus et al (6).

We found that children living in nuclear families reported lower HRQOL scores than those living in joint families. The difference of scores was statistically significant in social domain ( $\mathrm{p}$ value $=0.003$ ) (Table-3). Children living in such families may also be deprived of family affection and care necessary for their well-being, increasing their risk to develop psychological and behavioural problems as also observed by Fang et al (7); Wild et al (8).

The observations in the study show that the HRQOL of children not attending school was lower in physical, social and emotional domains (statistically significant difference in emotional and social domains, $\mathrm{p}$ values $0.032,0.005$ respectively). As suggested by the studies conducted by Nyamukapa et al (9) and colleagues in Zimbabwe, being out of school contributed to the greater psychological distress of AIDS affected children, because these children would lose a safe place for learning skills, sharing grief and developing peer networks.

The present study had some limitations that should be acknowledged. Being a cross-sectional study, we were unable to test whether there are changes in children's HRQOL over time. Moreover the response to the questionnaire was obtained differently for children greater than 12 years (self-administered) and less than 12 years (proxy administered). Despite the limitations, the findings are still applicable and can guide in the development of future interventions that promote care and support of children living in HIV/AIDS affected families. 


\section{References}

1. National Annual Report 2013-14.National Aids Control Organisation Ministry Of Health And Family Welfare. Webpage www.naco.gov.in

2. Varni, J. Seid, M. Rode, C., 1999. The PedsQL: Measurement Model for the Pediatric Quality of Life Inventory. Medical Care, 37(2):pp. 126-139.

3. Xu, T. Wu, Z. Rou, K. Duan, S. Wang, H., 2010. Quality of Life of children living with HIV/AIDS-affected families in rural areas in Yunnan, Acahina. AIDS Care, 22(3):pp.390-396.

4. Sengendo, J. \& Nambi, J. 1997. The psychological effect of orphanhood: a study of orphans in Raika district. Health Transit. Rev., 7(Suppl.): 105-124
5. Rotheram-Borus MJ,Draimin BH, ReidHM, MurphyDA. The impact of illness disclosure and custody plans on adolescents whose parents live with AIDS. AIDS. 1997;11:1159-1164

6. Chinqing Lin, Li Li, Alan Semaan , 2008 Children's body mass index and nutrition intake in HIV/AIDS.Vulnerable Child Youth Stud, 3(1): 16-23.

7. Fang X, Li X, Stanton B, Yan Hong Y, Zhang L, Zhao G, Lin D. Parental HIV/AIDS and psychosocial adjustment among rural Chinese children. Journal of Pediatric Psychology. 2009; 34(10):1053-1062. [PubMed: 19208701]

8. Wild J. The psychological adjustment of children orphaned by AIDS. Southern African Journal of Child and Adolescent Mental Health. 2002; 13:3-22

*Corresponding author:

Dr Sunit Pathak, 238A New Agra, Byepass Road, Agra, India- 282005

Phone: +91 8979834496

Email: drsunitpathak@gmail.com

Financial or other Competing Interests: None. 